\title{
KAJIAN ETNOBOTANI DAN KONSERVASI CENGKIH AFO DI TERNATE
}

\author{
Fadila Tamnge ${ }^{1}$, Yusnaini ${ }^{1}$ \\ ${ }^{1}$ Program Studi Peternakan Universitas Khairun; Kampus II Unkhair, Kel. Gambesi. Tlp (0921) 3110908 \\ Email:fadilatamnge@gmail.com,yusnaini@gmail.com \\ Manuscript recieved:15-11-2019 Revision Accepted: 30-11-2019
}

\begin{abstract}
Abstrak
Cengkih memiliki potensi yang baik untuk dikembangkan sebagai pusat budaya dan wisata sejarah di Kota Ternate. Keberadaan Cengkih Afo II sebagai cengkih tertua di dunia merupakan saksi bisu sejarah rempah Indonesia. Memanfaatkan, mempelajari, dan menyelamatkan Cengkih Afo merupakan upaya-upaya dalam strategi konservasi (Wilson 1992). Tujuan penelitian ini yaitu (1) mengidentifikasi aspek etnobotani Cengkih Afo pada masyarakat Desa Tongole, dan (2) mengidentifikasi aspek konservasi Cengkih Afo terutama kondisi habitatnya di alam. Penelitian dilaksanakan di Desa Tongole Kelurahan Marikurubu pada Agustus-September 2019. Metode yang digunakan yaitu wawancara dan inventarisasi vegetasi. Data hasil wawancara yang diperoleh dianalisis dengan cara melakukan peringkasan data, penggolongan, penyederhanaan, penelusuran dan pengaitan antar tema. Selanjutnya data disajikan secara deskriptif. Hasil inventarisasi vegetasi dianalisis menggunakan Indeks Nilai Penting dan Indeks keanekaragaman dan Kemerataan (Shannon-Wiener). Berdasarkan hasil pengukuran di lokasi penelitian, Masyarakat Desa Tongole memanfaatkan Cengkih Afo sebagai penyedap rasa alami dan tumbuhan obat. Terdapat 11 kategori pemanfaatan tumbuhan berguna oleh masyarakat Desa Tongole, dan Cengkih Afo III memiliki nilai uji pohon plus sebesar $72 \%$.
\end{abstract}

Kata kunci; Etnobotani, Konservasi, Cengkih Afo, Ternate

\section{PENDAHULUAN}

Cengkih merupakan tanaman rempah asli Maluku Utara/Kepulauan Maluku (Rukka 2010), dan telah diperdagangkan serta dibudidayakan secara turun-temurun dalam bentuk perkebunan rakyat. Penyebaran tanaman cengkih keluar Kepulauan Maluku dimulai sejak 1769, sedangkan ke Wilayah Indonesia lainnya dimulai pada 1870. Lingkungan ekologi seperti curah hujan, suhu, dan tanah vulkanik serta minimnya serangan hama penyakit sangat mendukung pengembangan tanaman cengkih di Maluku. Hadad et al. (2007) menyatakan, untuk tipe cengkih afo dari Maluku, saat ini tidak ada lagi generasi Afo I, yang masih ada tipe Afo II dan Afo III. Afo II dapat dipakai sebagai sumber benih Afo III dan dari populasi yang ada Afo II dapat dijadikan Blok Penghasil Tinggi (BPT) cengkih sebagai sumber benih komposit.

Cengkih memiliki potensi yang baik untuk dikembangkan selain sebagai penyedap rasa dan bahan obat alami, yaitu sebagai pusat budaya dan wisata sejarah di Kota Ternate. Keberadaan Cengkih Afo III sebagai cengkih tertua di dunia merupakan saksi bisu sejarah rempah 
Indonesia. Memanfaatkan, mempelajari, dan menyelamatkan Cengkih Afo merupakan upayaupaya dalam strategi konservasi (Wilson 1992). Upaya-upaya ini juga tergambar dalam budaya dan pengetahuan masyarakat lokal, seperti masyarakat Desa Tongole kelurahan Marikurubu di Kota Ternate.

Berdasarkan hal tersebut, kajian ilmiah yang dapat menjelaskan bagaimana pemanfaatan yang dilakukan oleh masyarakat terhadap spesies tersebut, maupun informasi mengenai kondisi Cengkih Afo di alam penting untuk dilakukan. Diharapkan informasi yang diperoleh dari kajian tersebut dapat digunakan sebagai dasar untuk mendukung upaya pelestarian sejarah dan budaya Cengkih Afo di Kota Ternate. Penelitian ini bertujuan (1) Mengidentifikasi aspek etnobotani Cengkih Afo pada masyarakat Desa Tongole, meliputi bagaimana pengetahuan masyarakat tentang Cengkih Afo, dan (2) Mengidentifikasi aspek konservasi Cengkih Afo.

\section{METODE PENELITIAN}

Penelitian dilaksanakan di Desa Tongole Kelurahan Marikurubu. Lokasi penelitian merupakan lokasi yang dapat mewakili etnis Ternate. Penelitian dilaksanakan pada AgustusSeptember 2019. Alat dan bahan yang digunakan antara lain aquades, pita meter, tally sheet, tali rapia, hagameter, higrometer, kamera, stopwatch, penggaris, kalkulator, buku kunci taksonomi tanah, buku identifikasi tumbuhan, dan kuisioner.

\section{Teknik Pengumpulan Data}

\section{Penentuan Sampel Wilayah Studi dan Responden}

Penentuan sampel wilayah untuk keperluan kajian etnobotani dilakukan secara purposive sampling. Wilayah studi yang dipilih berdasarkan pertimbangan bahwa lokasi tersebut dapat mewakili keberadaan etnis Ternate yang menjadi narasumber penelitian. Sementara itu, sampel wilayah studi untuk kajian keadaan Cengkih Afo dan aspek ekologisnya berdasarkan pada budaya dan sejarah Kota Ternate.

Masyarakat yang menjadi responden dalam penelitian ini adalah etnis Ternate yang tinggal dekat dengan keberadaan Pohon Cengkih Afo berada. Jumlah responden yaitu 30 orang yang mencakup masyarakat asli Desa Tongole. Pengambilan sampel responden dilakukan secara snowball sampling karena terbatasnya informasi mengenai masyarakat yang termasuk sebagai pengguna cengkih. Pengambilan responden dimulai dari masyarakat atau tokoh masyarakat yang telah diketahui memanfaatkan cengkih (key informan), dari keterangan responden tersebut kemudian dikumpulkan calon responden lain, calon responden tersebut memberikan informasi tentang calon responden yang lain, dan begitu seterusnya.

\section{Wawancara}

Wawancara dilakukan sebagai salah satu cara untuk mempelajari kajian etnobotani masyarakat lokal terhadap Cengkih Afo di Desa Tongole Kelurahan Marikurubu. Kegiatan ini dilakukan untuk memperoleh penjelasan mengenai aspek-aspek yang ingin diketahui dari segi pemanfaatan dan pengetahuan tentang Cengkih Afo oleh masyarakat selama ini. Selain menanyakan langsung kepada responden tentang hal-hal yang berkaitan dengan etnobotani cengkih, responden diberikan kuisioner yang dapat diisi untuk menerangkan bagaimana pemanfaatan dan pengetahuan masyarakat selama ini tentang cengkih. 


\section{Inventarisasi Vegetasi}

Untuk mempelajari kondisi Cengkih Afo dan keadaan ekologisnya di alam dilakukan inventarisasi vegetasi, yang mencakup spesies lain yang merupakan habitus pohon mulai tingkat semai pancang, tiang, dan pohon. Data ini diperlukan untuk melihat aspek konservasi Cengkih Afo. Sementara itu, pada jalur yang ditemukan cengkih, dicatat karakteristik cengkih yang ditemukan (diameter, tinggi, keterangan lainnya) dan vegetasi lainnya yang berada pada habitat cengkih. Pengamatan langsung dari kegiatan inventarisasi vegetasi dilakukan untuk mengetahui vegetasi lain yang termasuk habitus pohon di sekitar habitat cengkih afo. Meliputi keanekaragaman spesies, kekayaan spesies, kemerataan, dan kesamaan komunitas dalam unit pengamatan. Ukuran petak contoh untuk keperluan analisis vegetasi di areal berhutan dibedakan menurut tingkatan kelompok tumbuhan disajikan pada Tabel 1.

Tabel 1 Kategori pengelompokkan vegetasi dan luas petak ukur

\begin{tabular}{ccc}
\hline Kategori & Diameter $(\mathrm{cm})$ & Ukuran Petak $(\mathrm{m} \mathrm{x} \mathrm{m})$ \\
\hline Pohon & $>20$ & $20 \times 20$ \\
Tiang & $10-19$ & $10 \times 10$ \\
Pancang & $<10$ dan tinggi $\geq 1.5 \mathrm{~m}$ & $5 \times 5$ \\
Semai & Tinggi $<1.5 \mathrm{~m}$ & $2 \times 2$ \\
\hline
\end{tabular}

Pengambilan data dalam inventarisasi vegetasi dilakukan dengan menggunakan metode kombinasi jalur-garis berpetak (Kusmana 1997) disajikan pada Gambar 1.

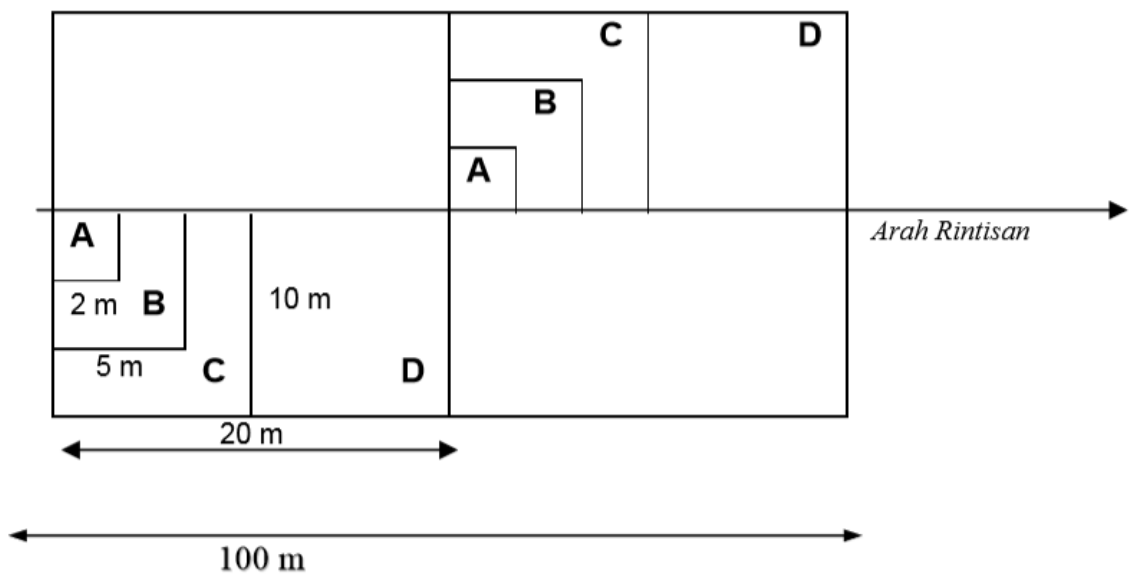

Gambar 1. Bentuk dan ukuran petak pengamatan inventarisasi vegetasi dengan metode kombinasi jalur dengan garis berpetak.

\section{Uji Pohon Plus dan Pengamatan Komponen Fisik Habitat Cengkih Afo}

Seleksi pohon plus dilakukan terhadap pohon kandidat (Cengkih Afo III) dan 5 pohon pembanding yang berada di sekitar pohon kandidat. Variabel yang diukur adalah tinggi total dan bebas cabang, lebar tajuk, kelurusan batang, diameter cabang, sudut percabangan, dan cacat lainnya. Jika nilai hasilnya lebih dari 70 maka pohon tersebut dapat dikatakan sebagai pohon plus yaitu pohon dengan fenotip unggul. Sementara itu, Keadaan fisik habitat cengkih afo yang diukur dan diamati, meliputi jenis tanah, ketebalan serasah, suhu, dan kelembaban lingkungan. 


\section{Analisis Data}

\section{Data Hasil Wawancara Etnobotani}

Data hasil wawancara diolah dan dianalisis dengan melakukan peringkasan data, penggolongan, penyederhanaan, penelusuran dan pengaitan antar tema. Selanjutnya data yang telah diperoleh disajikan secara deskriptif, sesuai dengan tema pembahasan yang ada sehingga mendukung dalam penarikan kesimpulan atau penentuan rekomendasi tindak lanjut.

\section{Komposisi dan Dominansi Spesies}

Data hasil inventarisasi vegetasi selanjutnya dianalisis untuk mengetahui komposisi dan dominansi spesiesnya. Dominansi suatu spesies akan ditunjukkan oleh besaran Indeks Nilai Penting (INP). INP untuk vegetasi tingkat tiang dan pohon merupakan penjumlahan dari nilai $K R+F R+D R$, sedangkan untuk vegetasi tingkat semai dan pancang, nilai INP $=K R+F R$. Persamaan-persamaan yang digunakan untuk menentukan nilai-nilai tersebut adalah sebagai berikut:

$$
\begin{array}{ll}
K=\frac{\text { Jumlah individu suatu spesies }}{\text { Luas plot pengamatan (Ha) }} & D=\frac{\text { Luas bidang dasar suatu spesies }}{\text { Luas plot pengamatan (Ha) }} \\
\text { KR }=\frac{\text { kepadatan suatu jenis }}{\text { total kepadatan jenis }} \times 100 \% & \text { DR }=\frac{\text { Dominasi suatu spesies }}{\text { Dominasi seluruh spesies }} \times 100 \% \\
F=\frac{\text { jumlah ditemukan spesies di suatu plot }}{\text { Jumlah total plot pengamatan }} & \\
\text { FR }=\frac{\text { Frekuensi suatu spesies }}{\text { Frekuensi seluruh spesies }} \times 100 \% &
\end{array}
$$

\section{Keanekaragaman Spesies Tumbuhan}

Untuk menentukan ukuran keanekaragaman spesies tumbuhan pada habitat Cengkih Afo, digunakan pendekatan indeks keanekaragaman (Shannon-Wiener) dan kemerataan (Magurran 2004).

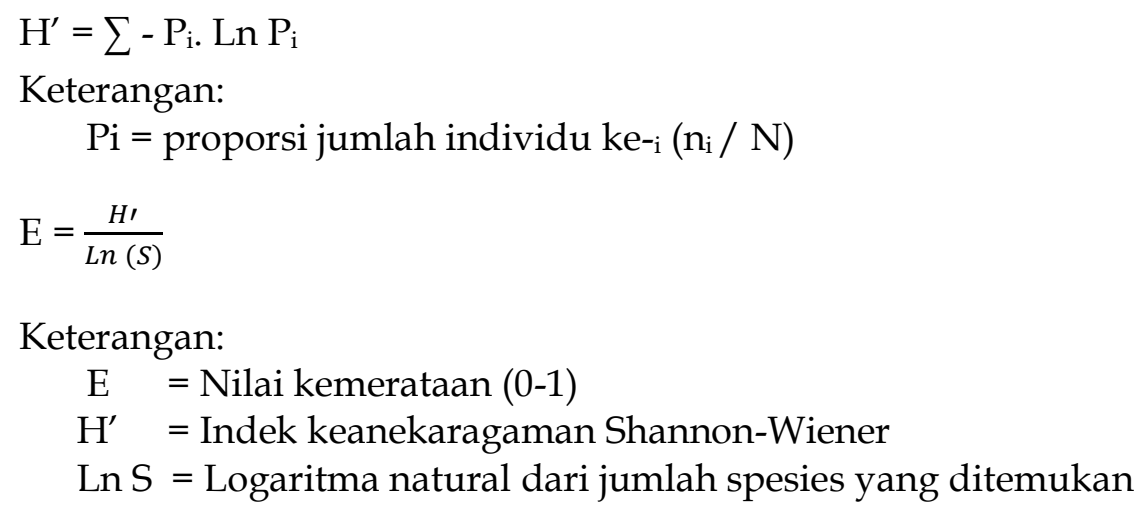




\section{HASIL DAN PEMBAHASAN}

\section{Karakteristik Responden}

Interaksi antara masyarakat Tongole dengan Kawasan HKm Tongole sangat erat karena sebagian masyarakat Tongole yang berdekatan dengan kawasan mempunyai kebun di dalam kawasan. Masyarakat Tongole menggarap lahan kawasan dikarenakan sebelum terbentuk menjadi HKm, Kawasan tersebut merupakan kebun campuran tua milik masyarakat yang sudah dibudidayakan secara turun-temurun. Menurut keterangan penduduk setempat, sebagian besar tanaman yang berada di sekitar kawasan $\mathrm{HKm}$ telah berumur lebih dari 40 tahun.

Pendidikan masyarakat Tongole tergolong masih rendah (Gambar 2). Hal ini diperoleh dari hasil wawancara, masyarakat Tongole dengan latar belakang tingkat pendidikan SD sebanyak 8 orang $(27 \%)$, SMP sebanyak 8 orang $(27 \%)$, SMA sebanyak 5 orang $(16 \%)$, S1 sebanyak 4 orang (13\%) dan yang tidak sekolah sebanyak 5 orang (17\%). Masyarakat Tongole memiliki sadar lingkungan tentang pentingnya menjaga kawasan $\mathrm{HKm}$ sebagai sumber penyangga kehidupan. Menurut hasil wawancara, masyarakat Tongole hanya akan mengambil kayu bakar dari batang atau ranting pohon cengkih yang sudah tumbang atau jatuh di atas tanah. Masyarakat Tongole percaya bahwa hal tersebut dilakukan agar dapat menjaga kuantitas debit air Tege-Tege yaitu sumber mata air yang terletak di kawasan HKm Tongole. Hal ini sesuai dengan pernyataan Fawnia et al. (2004), tidak ada hubungan antara tingkat pendidikan dengan tingkat kesadaran lingkungan. Masyarakat tradisional dengan tingkat pendidikan yang rendah pun mampu menjaga hutan dengan aturan-aturan adat yang berlaku.

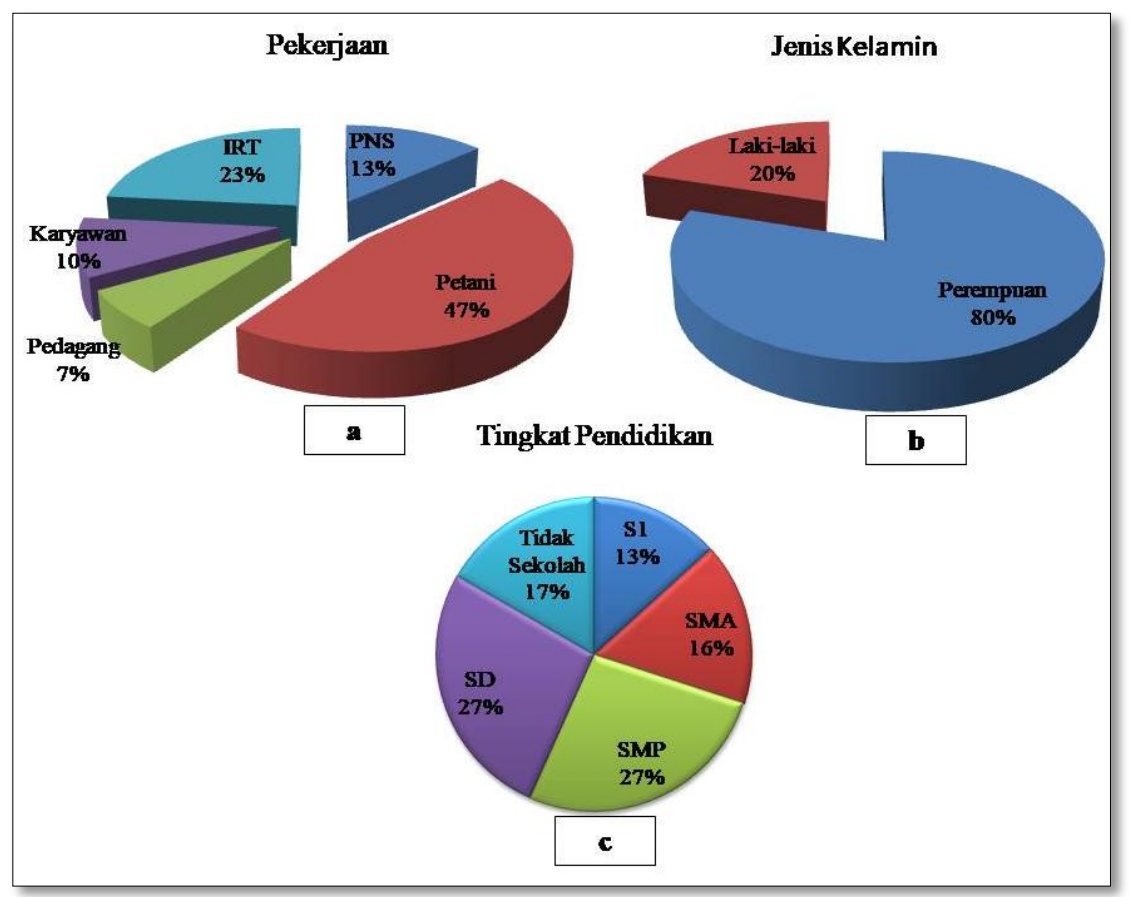

Gambar 2. [a] Jumlah pekerjaan responden, [b] jenis kelamin responden, dan [c] tingkat pendidikan responden.

Sementara itu, pekerjaan masyarakat Tongole rata-rata bekerja sebagai petani yaitu sebanyak 14 orang $(47 \%)$, pedagang sebanyak 2 orang $(7 \%)$, karyawan sebanyak 3 orang $(10 \%)$, Ibu Rumah Tangga sebanyak 7 orang (23\%), dan PNS sebanyak 4 orang (13\%). Masyarakat yang bekerja sebagai petani membuka lahan di kawasan HKm untuk dijadikan kebun sawi, 
singkong dan jagung. Sawi dibudidayakan selama 24 hari, kemudian dipanen dan dijual ke pasar dengan harga sepuluh ribu rupiah per ikat, sedangkan singkong dan jagung dipanen untuk kebutuhan pangan rumah tangga.

\section{Persepsi Masyarakat dalam Pemanfaatan Cengkih Afo}

\section{Pemanfaatan Sebagai Penyedap Rasa Alami}

Pemanfaatan bunga Cengkih Afo oleh masyarakat Desa Tongole adalah sebagai penyedap rasa alami yakni untuk menguatkan rasa masakan dan minuman. Pengetahuan tentang penyedap rasa dari Cengkih Afo merupakan warisan nenek moyang dalam mengolah masakan sehingga pemanfaatan Cengkih Afo dapat dikatakan memiliki nilai ekonomi dan makanan.

\section{Pemanfaatan Tumbuhan Obat}

Pemanfaatan lain Cengkih Afo adalah sebagai tumbuhan obat. Daun Cengkih Afo yang direbus dapat dimanfaatkan sebagai bahan ratus untuk ibu post partum, kemudian daun yang sudah diekstrak sebagai minyak atsiri dapat dimanfaatkan untuk meningkatkan kesehatan tulang, mengobati sakit maag, dan mengendalikan gula darah. Masing-masing etnis mempunyai pengalaman dan kepercayaan tertentu yang mempengaruhi pengetahuannya terhadap manfaat Cengkih Afo. Pengetahuan pemanfaatan Cengkih Afo untuk manfaat lainnya masih terbatas pada sebagian komunitas tertentu dalam arti pengetahuan tersebut belum diketahui dan dikenal secara luas.

\section{Potensi dan pemanfaatan tumbuhan berguna}

Berdasarkan kelompok kegunaan, spesies-spesies tumbuhan hasil etnobotani di HKm Desa Tongole dapat dikelompokkan kedalam 11 kelompok kegunaan. Berdasarkan hasil etnobotani kelompok kegunaan terbanyak yaitu tumbuhan obat sebanyak 28 jenis,diikuti oleh tumbuhan untuk keperluan ritual, adat dan keagamaan sebanyak 7 jenis. Untuk lebih jelasnya, kelompok kegunaan spesies-spesies tumbuhan hasil etnobotani tersaji pada Gambar 3 berikut.

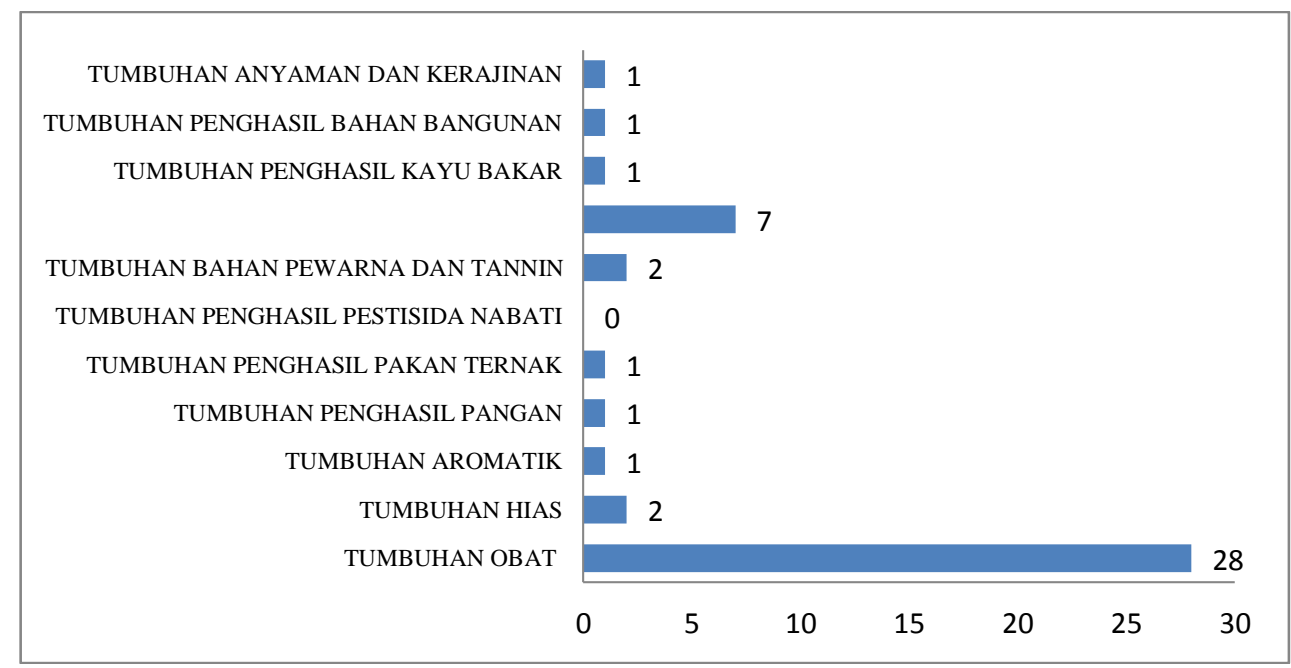

Gambar 3. Pemanfaatan tumbuhan di Desa Tongole

Penggunaan tumbuhan oleh masyarakat Desa Tongole dalam pemenuhan kebutuhan hidup menggunakan seluruh bagian tumbuhan mulai dari bagian akar sampai daun. Bagian yang paling banyak digunakan adalah daun sebanyak 30 jenis $(63 \%)$ dan yang paling terkecil 
adalah batang kering, bunga, dan daun kering sebanyak 1 jenis (2\%). Selengkapnya tersaji pada Tabel 2.

Tabel 2. Bagian Tumbuhan yang Digunakan oleh Masyarakat

\begin{tabular}{clcc}
\hline No & Bagian yang digunakan & Jumlah jenis & Persentase $(\%)$ \\
\hline 1 & akar & 2 & 4 \\
2 & Batang & 2 & 4 \\
3 & Batang kering & 1 & 2 \\
4 & Buah & 4 & 8 \\
5 & Bunga & 1 & 2 \\
6 & daun & 30 & 63 \\
7 & daun kering & 1 & 2 \\
8 & Kulit batang & 2 & 4 \\
9 & Rimpang & 5 & 11 \\
\hline
\end{tabular}

Jumlah bagian terbanyak dari tumbuhan yang dimanfaatkan sesuai dengan penelitian lain, diantaranya penelitian Hidayat (2009) tentang Etnobotani Masyarakat Kampung Adat Dukuh di Garut yang menyebutkan bahwa dari 292 spesies tumbuhan yang ditemukan, 110 jenis diantaranya diambil pemanfaatannya dari bagian daun. Menurut Fakhrozi (2009), pemanfaatan daun tidak menimbulkan pengaruh besar terhadap pertumbuhan suatu spesies dibandingkan dengan batang atau akar dari tumbuhan tertentu.

\section{Komunitas Tumbuhan}

Peranan suatu spesies dalam komunitas dapat dilihat dari besarnya Indeks Nilai Penting (INP), dimana spesies yang mempunyai nilai INP tertinggi merupakan spesies dominan. INP merupakan parameter kuantitatif yang dapat dipakai untuk menyatakan tingkat dominansi (tingkat penguasaan) spesies-spesies dalam suatu komunitas tumbuhan (Indriyanto 2006). Hal ini menunjukkan bahwa spesies tersebut memiliki tingkat kesesuaian terhadap lingkungan yang lebih tinggi dibandingkan spesies lain. Daftar INP terbesar pada masing-masing tingkat pertumbuhan di Desa Tongole disajikan pada Tabel 3.

Tabel 3. Indeks Nilai Penting Tumbuhan di Desa Tongole

\begin{tabular}{llc}
\hline Tingkat Pertumbuhan & Jenis & INP (\%) \\
\hline Semai & Tumbuhan Pita & 67.92 \\
Pancang & Angsana & 137.91 \\
Tiang & Kenari & 66.67 \\
Pohon & Cengkih Zanzibar & 70.07 \\
\hline
\end{tabular}

Berdasarkan hasil pengamatan, INP tertinggi pada masing-masing tingkat pertumbuhan yaitu semai, pancang, tiang, pohon adalah Tumbuhan pita (67.92\%), angsana (137.91\%), kenari $(66.67 \%)$, dan Cengkih Zanzibar $(70.07 \%)$, sedangkan jenis tumbuhan pada masing-masing tingkat pertumbuhan yang memiliki nilai INP terkecil adalah lemon cui dan keladi $(3.32 \%)$, cengkih Zanzibar (18.31\%), kelapa (36.47\%), dan nangka (4.81\%). 
Sementara itu, keanekaragaman spesies merupakan ciri tingkatan komunitas berdasarkan organisasi biologisnya. Keanekaragaman spesies dapat digunakan untuk menyatakan struktur komunitas, juga dapat digunakan untuk mengukur stabilitas komunitas, yakni kemampuan suatu komunitas untuk menjaga dirinya tetap stabil meskipun terdapat gangguan pada komunitas tersebut (Indriyanto 2006).

Keanekaragaman spesies yang tinggi menunjukkan bahwa suatu komunitas memiliki kompleksitas tinggi karena spesies yang terjadi dalam komunitas itu sangat tinggi. Indeks kemerataan memiliki selang 0-1. Nilai indeks kemerataan mendekati 1, maka sebaran individu antar spesies relative merata, sedangkan bila mendekati nilai 0 maka sebaran individu antar spesies tidak merata (Magurran 2004). Rekapitulasi nilai indeks keanekaragaman Shannon Wiener dan Indeks kemerataan di HKm Desa Tongole disajikan pada Tabel 4.

Tabel 4. Indeks Keanekaragaman dan Kemerataan Shannon-Wiener

\begin{tabular}{lcc}
\hline Tingkat Pertumbuhan & $\mathrm{H}^{\prime}$ & $\mathrm{E}$ \\
\hline Semai & 1.61 & 0.58 \\
Pancang & 0.58 & 0.53 \\
Tiang & 1.73 & 0.97 \\
Pohon & 1.71 & 0.74 \\
\hline
\end{tabular}

Keanekaragaman dan kemeratan spesies tumbuhan tertinggi yaitu pada tingkat pertumbuhan tiang, kemudian diikuti oleh tingkat pertumbuhan pohondan semai. Pancang merupakan tingkat pertumbuhan dengan nilai $\mathrm{H}^{\prime}$ dan $\mathrm{E}$ terendah. Adanya perbedaan nilai proporsi kekayaan dan kemerataan spesies disebabkan oleh adanya perbedaan keragaman dan kelimpahan di masing-masing tingkat pertumbuhan. Menurut Odum (1958), indeks keanekaragaman dipengaruhi oleh kekayaan spesies, sementara kemerataan dipengaruhi oleh kelimpahan individu. Desmukh (1992) mengungkapkan bahwa keanekaragaman menjadi lebih besar jika kelimpahan populasi satu sama lain merata. Keragaman tidak hanya menyangkut kekayaan spesies namun juga kemerataan dari kelimpahan individu tiap spesies.

\section{Konservasi Cengkih Afo}

Hasil penelitian identifikasi pohon plus yang telah dilakukan di Desa Tongole dapat dilihat pada Tabel 5.

Tabel 5 hasil Pengujian Pohon Plus Terhadap Pohon cengkih Afo III

\begin{tabular}{clc}
\hline No & Variabel Perhitungan & Poin $(\%)$ \\
\hline 1 & Tinggi Total & 10 \\
2 & Diameter & 20 \\
3 & Tbc & 0 \\
4 & sudut cabang & 5 \\
5 & Bentuk Batang & 27 \\
6 & Diameter Cabang & 0 \\
7 & Ketahanan Penyakit & 5 \\
8 & Pemangkasan Alami & 0 \\
9 & Produksi Buah & 5 \\
\multicolumn{2}{r}{ Total } & 72 \\
\hline
\end{tabular}


Dari hasil pengamatan langsung di lapangan, pohon Cengkih Afo III tercatat memiliki penampakan fisik yang baik, yaitu pohon yang lebih dominan penampakan fisiknya dibandingkan dengan pohon pembanding di sekitarnya. Kenampakan fisik yang diamati meliputi diameter, tinggi total, tinggi bebas cabang, kelurusan batang, silindris batang, permukaan batang, dan cacat lain. Seleksi pohon merupakan langkah awal dalam suatu program penangkaran maka seleksi pohon plus dikatakan sebagai pondasi yang akan memberikan bahan-bahan yang bagus bagi program penangkaran selanjutnya.

Dari hasil pengukuran didapatkan jumlah total hasil pengukuran yaitu $72 \%$. Angka tersebut bermakna bahwa Cengkih Afo III tercatat sebagai pohon plus karena nilai yang diperoleh lebih dari $70 \%$. Seleksi pohon plus merupakan langkah awal dari program pemuliaan. Dalam seleksi pohon plus, pohon akan diseleksi atas keunggulan nyata dari pohon rata-rata atau pohon pembanding di sekitarnya, namun pohon tersebut tidak dapat diketahui genetiknya sampai keturunannya di uji untuk memperoleh nilai sebagai induk bagi program pemuliaan. Selanjutnya masing-masing hasil pengukuran kondisi lingkungan terhadap suhu, kelembaban, jenis tanah, dan ketebalan serasah disajikan pada Tabel 6 .

Tabel 6. Hasil Pengukuran terhadap kondisi lingkungan di Desa Tongole

\begin{tabular}{ll}
\hline Variabel Pengukuran & Nilai \\
\hline Suhu $\left({ }^{0} \mathrm{C}\right)$ & 27 \\
Kelembaban $(\%)$ & 63 \\
Ketebalan Serasah $(\mathrm{cm})$ & 6.7 \\
Jenis Tanah & Regosol \\
\hline
\end{tabular}

\section{KESIMPULAN}

Kesimpulan dari hasil penelitian ini adalah (1) Masyarakat Desa Tongole memanfaatkan Cengkih Afo sebagai penyedap rasa alami dan tumbuhan obat, dan terdapat 11 kategori pemanfaatan tumbuhan berguna oleh masyarakat Desa Tongole, serta (2) Cengkih Afo III memiliki nilai uji pohon plus sebesar $72 \%$, bermakna bahwa Cengkih Afo III tercatat sebagai pohon plus dalam rangka penentuan upaya awal dalam suatu program penangkaran untuk konservasi jenis.

\section{SARAN}

Saran dari penelitian ini yaitu perlu adanya pengembangan lebih lanjut terhadap Cengkih Afo III sebagai spesies tanaman unggulan untuk meningkatkan pendapatan masyarakat di Desa Tongole dan perlu adanya pembinaan bagi masyarakat Desa Tongole agar dapat mempertahankan pengetahuan etnobotaninya.

\section{UCAPAN TERIMA KASIH}

Penelitian ini didanai oleh dana DIPA Universitas Khairun 2019. Kami berterima kasih kepada Kepala Desa dan Ketua Rukun Tetangga Desa Tongole yang sudah membantu selama proses penelitian. Kami juga berterima kasih kepada asisten lapangan kami yaitu Zulkarnain Riswan Umanahu, Nurul Salsabila, dan Gita Nurarista atas bantuan survey dan pengumpulan data. Kepada Ibu Laswi Irmayanti atas bantuan analisis uji pohon plus dan kepada Ibu Sri DAS dan Bapak Suratman Sujud atas saran dan masukan yang membangun. 


\section{DAFTAR PUSTAKA}

Backer CA, Brink BVD. 1963. Flora of Java (Spermatophytes Only) Vol. I. Wolters-Noordhoff N.V. Goninger. Netherlands.

Desmukh I. 1992. Ekologi dan Biologi Tropika. Jakarta: Yayasan Obor Indonesia.

Fakhrozi I. 2009. Etnobotani masyarakat Suku Melayu Tradisional di Sekitar Taman Nasional Bukit Tigapuluh [Skripsi]. Bogor: Fakultas Kehutanan Institut Pertanian Bogor.

Hadad EAM, Herman M, Sukur M, Defina, Yuniati N. 2007. Blok Penghasil Tinggi Cengkeh Afo II Sebagai Sumber Benih di Ternate Maluku Utara. Hlm. 270-278. Prosiding Seminar Nasional Rempah, 21 Agustus 2007. Pusat penelitian dan Pengembangan Perkebunan, Bogor.

Hidayat S. 2009. Etnobotani masyarakat Kampung Adat Dukuh di Garut, Jawa Barat [Skripsi]. Bogor: Fakultas Kehutanan Institut Pertanian Bogor.

Indriyanto. 2006. Ekologi Hutan. Jakarta: PT. Bumi Aksara.

Kusmana C. 1997. Metode Survey Vegetasi. Bogor: IPB Pr.

Magurran AE. 2004. Measuring Biological Diversity. Oxford: Blackwell.

Odum EP. 1958. Fundamental of Ecology $2^{\text {nd }}$ Edition. Philadelphia : Saunders Pr.

Purwanto Y, Waluyo EB. 1992. Etnobotani Suku Dani di Lembah BAliem: Tinjauan terhadap Pengetahuan dan pemanfaatan Sumberdaya Tumbuhan. Di Dalam Prosiding Seminar dan Lokakarya Nasional Etnobotani I. Cisarua, Bogor.

Rukka, EAW. 2010. Cengkeh (Syzigium aromaticum). http://management01.wordpress. com/2010/10/29/mengenaltanaman cengkeh. [17 Maret 2019].

Sudarmadji. 2002. Pentingnya Pemberdayaan Masyarakat Dalam Upaya Konservasi Sumberdaya Alam Hayati di Era Pelaksanaan Otonomi Daerah. Ilmu Dasar 3:50-55.

Wilson EO. 1992. The strategy for biodiversity conscervation. Dalam: Global biodiversity strategy (WRI, IUCN, UNEPP. Pp. 19-36. 